\title{
Government spending, the exchange rate and growth: empirical evidence for Latin America
}

\author{
Gastos do governo, câmbio e crescimento: \\ evidências empíricas para a América Latina
}

MORITZ CRUZ*

JOSUE ZAVALETA**

\begin{abstract}
RESUMO: Utilizando dados de economias selecionadas da América Latina para o período 1990-2017, este artigo visa fornecer evidências empíricas sobre o efeito da desagregação dos gastos do governo na taxa de câmbio. Nossos resultados indicam que o investimento do governo deprecia a taxa de câmbio, enquanto o consumo do governo, por outro lado, a aprecia. Ambos os efeitos são, no entanto, bastante pequenos. Nossos resultados corroboram a literatura recente que mostra que a relação entre os gastos do governo e a taxa de câmbio é ambígua, desafiando a ideia geral aceita de que os gastos do governo inevitavelmente valorizam a taxa de câmbio, tendo, portanto, efeitos negativos sobre o setor comercializável e sobre o crescimento. No geral, nossos resultados nos permitem sugerir que o crescimento pode ser estimulado principalmente por meio de investimentos do governo, sem efeitos prejudiciais sobre a taxa de câmbio.
\end{abstract}

PALAVRAS-CHAVE: Gastos do governo; taxa de câmbio; política industrial; crescimento e desenvolvimento; América Latina.

ABSTRACT: Using data of selected economies of Latin America for the period 1990-2017, this paper aims to provide empirical evidence regarding the effect of disaggregate government spending in the exchange rate. Our results indicate that government investment depreciates the exchange rate whereas government consumption, on the other hand, appreciates it. Both effects are, however, rather small. Our findings support recent literature showing that the relationship among government spending and the exchange rate is ambiguous, challenging the general accepted idea that government spending inevitably appreciates the exchange rate, having thus negative effects on the tradable sector and on growth. Overall, our results allow us to suggest that growth can be stimulated particularly via government investment without detrimental effects on the exchange rate.

\footnotetext{
* Universidad Nacional Autónoma de México, Instituto de Investigaciones Económicas, Coyoacán, Mexico. E-mail: aleph398@gmail.com. Orcid: https://orcid.org/0000-0002-3771-8302.

** Benemérita Universidad Autónoma de Puebla, Facultad de Economía, Puebla, México. E-mail: josue. zavaleta@correo.buap.mx. Orcid: https://orcid.org/0000-0002-5171-9280. Submitted: 13/February/19; Approved: 16/February/2020.
} 
KEYWORDS: Government spending; exchange rate; industrial policy; growth and development; Latin America.

JEL Classification: 011; 025; E12; E62.

\section{INTRODUCTION}

The management of public expenditure and its effect on the exchange rate has often represented a major challenge for policymakers because their relationship has been long put at the centre of analysis and debate. The most accepted outcome among these policy tools is that an expansion of public expenditure appreciates the exchange rate, thereby reducing the competitiveness of the tradable sector affecting overall negatively the economy (see, among others, Ricci et al., 2008; Froot and Rogoff, 1991; De Gregorio et al., 1994; Chinn, 1999; Bénetrix and Lane, 2013). From here, it has been suggested that the best policy option to aid the traded sector is to keep a fiscal balance or surplus.

It is important to notice, however, that most of the theoretical and empirical studies omit to analyse separately the effect of government consumption and investment on the exchange rate. This is relevant because both public consumption and investment affect differently the exchange rate. In fact, in recent works, it has been suggested at the theoretical level that when the burden of government investment lies on the no-traded sector, the exchange rate depreciates. Further, the empirical exercises of these works, focused mainly on developed economies, have shown that whereas government consumption appreciates the exchange rate, government investment depreciates it or that both effects could cancel each other, leaving the exchange rate unaffected (see Galstyan and Lane, 2009a, 2009b; Caputo and Fuentes, 2012; Bénetrix and Lane, 2013; Cakrani et al., 2013; Moreno and SeguraUbiergo, 2014). In this sense, it can be argued that the effect of government spending on the exchange rate is ambiguous and as a result the policy recommendation just mentioned could be dismissed.

This paper attempts to contribute to this debate on the literature by exploring in which direction public consumption and public investment affect the exchange rate in Latin America. We use data for the period 1990-2017. The exercise is relevant because, to the best of our knowledge, is the first attempt to explore a developing region in this regard. Furthermore, Latin America does not characterise for using fiscal policy to stimulate growth - let alone to alleviate periods of crisis - due precisely to the fear to deteriorate the traded sector, so by investigating how disaggregate public spending affects the exchange rate could offer insights on which way to proceed, via consumption or investment, in order to use fiscal expansion to support growth and development.

In addition to the empirical contribution, the paper seeks to suggest, at the theoretical level, other factors that reinforce the argument about the unpredictable 
effect of government spending on the exchange rate. These factors are the size of the multiplier, the degree of idle capacity and income demand elasticities.

The paper is set up as follows. Section 2 discuss, at the theoretical level, why government spending has an unpredictable effect on the exchange rate. Section 3 presents and analyses the results of our econometric exercise. Section 4 concludes.

\section{IS THE RELATIONSHIP BETWEEN PUBLIC SPENDING AND THE EXCHANGE RATE UNAMBIGUOUS?}

In general., since the mid-1980s economies, developed and developing alike, have remained reluctant to implement an expansionary fiscal policy, preferring to maintain budget balance or surplus. This choice is not unexpected, steams from what some stream of influential theoretical and empirical works has suggested in terms of the effect of government spending on the exchange rate: namely, that former unambiguously appreciates the latter.

Perhaps one of the most influential models in this regard is the Mundell-Fleming theoretical approach. As it is well-known, this model argues that an increase on government spending, assuming free mobility of capital and a floating exchange rate regime, appreciates the exchange rate, having not, in addition, an expansionary effect on output. An alternative rationale used to explain why for sure public expenditure has a negative effect on the exchange rate is underpinned on the idea that when most of it is channelled to the non-tradable sector, the increased demand for goods and services, will cause, assuming full employment, higher domestic prices, appreciating in turn the real exchange rate (see Kollmann, 2010; Ravn et al., 2012; Sachs and Wyploz, 1984; Bergstrand, 1981).

Empirically, a recent work, using data of 48 countries, combining advanced and developing economies, supports the above arguments by finding that a 1 percentage point increase in the ratio of government consumption is associated with a 3 percentage points appreciation of the real effective exchange rate (Ricci et al., 2008; see also Ravn et al., 2012). As can be seen, in sum, both theoretical and empirical woks suggest a straightforward relationship between government expenditure and the exchange rate; that is, the former always appreciates the latter. This implies, at the political economy level, that the best way to promote the traded sector, and in this way economic growth, is to maintain government spending balanced, hence no affecting negatively the exchange rate.

The aforementioned relationship, however, can be deceiving, as it may be possible that government spending affects the exchange rate in a different direction, challenging the policy recommendation just mentioned. Bhaduri and Matzner (1990), for example, following up the Mundell-Fleming approach, point out that it could be the case that government spending depreciates the exchange rate. Their argument is that nothing in this model suggests that the current account deficit, caused by the reinforcing effect derived from the initial expansion of output and the appreciation of the exchange rate, will be corrected. So, if the current account deficit continues 
to grow (gauged as a share of GDP) there will be an increasing expectation that, in order to correct the external imbalance, a depreciation of the exchange rate will be needed. This expectation could be in fact self-fulfilling as the means to finance the current account start to erode. On the other hand, international reserves can be exhausted if external lenders, due to the size of the current account (or any other weakened fundamental), start to attack the currency. Once this dynamic is set in motion, the currency will be inevitably depreciated (see Thirlwall, 2003). Government spending, in sum, would have influenced ultimately the exchange rate toward depreciation. So, as can be seen, the effect of government spending on the exchange rate is not as sharp as is generally thought. It could appreciate it, but there is also the possibility that it could depreciate it.

This result, by the way, is based on the idea that the government only spends on consumption (meaning injections of income to households via wages and to firms via purchases of goods and services). In other words, the effect of government investment on the exchange rate is omitted. And this is not a trivial issue because government investment (meaning spending on projects that substitutes or complements the private sector investment, particularly infrastructure projects on transport, health and/or education like roads, ports, airports, hospitals, schools, research centres, etc.) works on the exchange rate through different channels at the same time, making very difficult to predict what the final upshot will be.

So, when the composition of government spending is introduced into the analysis, something that is generally omitted in most of the studies, the ambiguous and unpredictable effect on the exchange rate stands out.

Government consumption, for example, might have the effect on the real exchange rate just pointed out above, that is, appreciate it, but only if conditions like full capacity and a high multiplier prevail. However, if we think that the new income that households receive is retained as savings or used to payoff or service outstanding debts, nor the domestic demand neither prices will necessarily grow, leaving the exchange rate unaffected; but even if the new income is spent, its effect on the domestic demand will depend on the propensity to import, which in turn determines the size of the multiplier. If the propensity to import is high, then it is likely that the trade deficit worsens as consumption grows, leading to the outcome described previously, that is pushing ultimately the exchange rate towards depreciation. On the other hand, if the multiplier is high, but there is spare productive capacity, then the exchange rate might remain unchanged.

Now, public investment has both short- and long-term effects on the exchange rate. It, for instance, like public consumption, expands the demand for goods in the short term (for recent empirical evidence of this, see Hebous and Zimmerman, 2016). ${ }^{1}$ If firms are producing below full capacity, prices will not necessarily increase, leaving the exchange rate unaffected. If firms import substantially their inputs or

\footnotetext{
${ }^{1}$ Public investment has also substantial positive impact on domestic welfare according to Ganelli and Tervala (2015). Their work shows that a dollar spent by the government on investment raises welfare
} 
final goods, then the trade deficit will worsen, pushing the exchange rate towards depreciation.

In the long-term, government investment affects productivity positively (see, inter alia, Aschauer, 1989; Pressman, 1994; Galstyan and Lane, 2009a; IMF, 2014; OECD, 2016). Health care and educational expenditures are likely to cause healthier and more educated labour force, affecting positively their productivity. Also, as firms increase their sales, more revenue is left for research and development (R\&D) projects, which are also an important source of technology, innovation and thus of productivity. Higher profits can also be reinvested on improved raw material and/ or machinery. This also improves productivity. When the government invests on infrastructure, like roads, railroads, airports and ports, also advance productivity by reducing the amount of time that it takes to transport raw material and finished goods. ${ }^{2}$ Of course, new roads and public transport also reduce the time people spend commuting to work, a fact that may also affect their productivity positively. In addition, R\&D made by the government is a proved source of new technology, having also a positive impact on productivity. In sum, if productivity increases thanks to government investment, it can be argued in principle that the exchange rate will depreciate because prices will not necessarily grow. This result can be expected whether or not there is full capacity, but as along as (wages and) prices do not increase proportional to productivity.

However, the opposite result can also be hold. The argument to sustain that increases on productivity, thanks to government investment, appreciate the exchange rate can be elaborated via the Harrod-Balassa-Samuleson (HBS) effect, which assumes that full capacity exists and that labour markets are competitive within each country, leading to wage equalization between traded and non-traded sectors. So, the HBS effect essentially predicts that increased productivity will appreciate the real exchange rate via higher domestic wages and prices (see Obstfeld and Rogoff, 1996).

There is of course the possibility that if productivity disproportionally increases in the non-traded sector, as the bulk of government investment falls on that sector, then the result, if this sector has idle productive capacity, could be that prices may decrease, leading thus the exchange rate to depreciate. If, on the other hand, prices rise in tandem with productivity due to full capacity, then the exchange rate will appreciate (see Galstyan and Lane, 2009a). Finally, both sectors could take advantage of government investment, increasing productivity symmetrically. Here the final effect on the exchange rate will depend on which assumptions prevail regarding the size of the pass-through of productivity to prices and whether there is or not full capacity.

by an equivalent of 0.8 dollars of private consumption. Government investment can also have an important and positive effect on unemployment when it is done in labor-intensive projects.

${ }^{2}$ It is important to stress that Keynes himself was aware of the superiority of government investment over government consumption and for this reason he proposed using mainly government investment to influence positively the economy (see Smithin, 1989; Pressman, 1994; Davidson, 2007). 
In addition to the arguments presented, we can elaborate on how prices respond to demand patterns to show the unpredictable effect of government investment on the exchange rate. The idea here is to introduce income-demand elasticities into the analysis. This logic, it is important to notice, is particularly well-suited to differentiate the effects of government investment among rich and poor economies.

As it is well known, demand patters, which are driven by the evolution of income, influence sectorial prices differently, depending on the size of the income elasticity of demand for traded goods (namely manufactures) and non-traded goods (namely services) (see Bersgtrand, 1981). In theory, for poor countries, one would expect to see the income elasticity of demand for manufactures above unity, whereas the income elasticity of demand for services below unity (Rowthorn and Rasmawamy, 1999).

So, assume that government investment falls mostly on the traded sector, this implies that as productivity and income grow, the demand for traded goods will be higher than the demand for services. This increased demand, however, will not necessarily push prices up in the traded sector because productivity here, grows faster than elsewhere (see Kaldor, 1966), which alleviates upward price pressures; also, there may be spare capacity, leading, in sum, to a depreciated exchange rate. If, on the other hand, most of government investment goes to the non-traded sector, productivity and income will grow, but the demand for services will increase slowly, thereby leaving unaffected the exchange rate. Evidently, if both sectors take advantage of public investment, there is no reason to expect increases in prices, so the exchange rate will remain unaffected. As can be seen, thus, for poor or developing economies, government investment, due to demand patterns, could overall influence the exchange rate towards depreciation or leave it unaffected.

On the other hand, for high income economies, one would expect to see the income elasticity of demand for services (luxuries) higher than unity, whereas the income elasticity of demand for manufactures below (or equal) to unity. If government investment falls mostly on the non-traded sector, then prices will go up, appreciating the exchange rate. If, on the other hand, the traded sector burdens government investment, then prices will not necessarily increase thanks, once again, to the substantial productivity growth that this sector observes and the existence of idle productivity capacity. But because the demand for luxuries will increase, prices will grow. As a result, the exchange rate will appreciate. If both sectors share symmetrically government investment, the exchange rate will appreciate. This expected result is in contrast with that reported in recent works (see Galstyan and Lane, 2009a, 2009b; Bénetrix and Lane; 2013), which, as we mentioned, argue that the huge growth of productivity on the non-traded sector depreciates the exchange rate. Their analysis omits, however, what happens after productivity and income increase. ${ }^{3}$

\footnotetext{
${ }^{3}$ Galstyan and Lane (2009a), for example, present a mathematical model, in neoclassical lines, that exhibits the unpredictable effects of government spending on the exchange rate. Their emphasis is on how sensitive is the productivity of the non-traded and traded sectors to public consumption and
} 
As can be seen, in sum, it is unlikely to know a priori in which direction government expenditure would affect the exchange rate. It might either appreciate it, depreciate it or leave it unaffected, all depending on the size of the current account, the size of the multiplier and on how prices move, which in turn respond to increases on productivity, the size of the income elasticities of demand and how much productive capacity firms are using.

It seems, thus, that the effect of government spending, particularly government investment, on the exchange rate is, paraphrasing Galstyan and Lane (2009a, p. 1239), an empirical question that cannot be settled theoretically. This is why, it is paramount, before refrain an expansionary fiscal strategy to attempt to shed some empirical light on this relationship. This is the aim of the next section using data of Latin America, a region that as far as we know has not been explore in this sense.

\section{PUBLIC EXPENDITURE AND THE EXCHANGE RATE: AN EMPIRICAL EXERCISE FOR SELECTED LATIN AMERICAN ECONOMIES}

Unlike most of the recent literature that investigates the empirical relationship among disaggregate government expenditure and the exchange rate, we explore a sample of Latin American economies. In this sense, our work is, as far as we known, the first attempt to assess that relationship focusing on developing economies. This is important because, as we have emphasised, the policy implications of the results could be relevant for countries at this stage of development.

Based on data availability for the period 1990-2017, we selected thirteen Latin American economies: Argentina, Bolivia, Colombia, Chile, Dominican Republic, Costa Rica, El Salvador, Guatemala, Honduras, Mexico, Panama, Paraguay and Venezuela.

During this period, the behaviour of government expenditure in general terms shows a moderate increasing trend, going from $15 \%$ in 1990 to $20.5 \%$ of GDP in 2017 (see Figure 1). At the disaggregated level, consumption spending, with the exception of Chile, Guatemala and Venezuela, grew between 1990 and 2005. However, during 2005-2017, except, for Panama, all countries in the sample increased their current spending. For some economies, like Argentina, the overall increment was quite large, representing 10 percentage points of GDP between 1990 and 2017; similar cases are Colombia, the Dominican Republic and Venezuela, where the increment represented around 11.9 and 9.8 percentage points of GDP, respectively. For the rest of the economies, as can be seen, government consumption has increased just barely (like Guatemala) or has been within the range of 3 to 5 percentage points of GDP (see Figure 2). For the complete sample of countries government consumption increased on average 4.1 percentage points, going from $12.4 \%$ in 1990 to

investment. The model does not incorporate the influence of the trade balance or multiplier effects and gets rid-off the elasticities issue by assuming a unitary income elasticity of demand in both sectors. 
$16.5 \%$ of GDP in 2017. In 2014, it achieved its highest level, reaching $17.3 \%$ of GDP (see Figure 1). It is important to notice that consumption expenditure accounts for most (around $80 \%$ on average) of total public spending.

Figure 1: Total government expenditure in Latin America (\% of GDP), 1990-2017

(Selected economies)

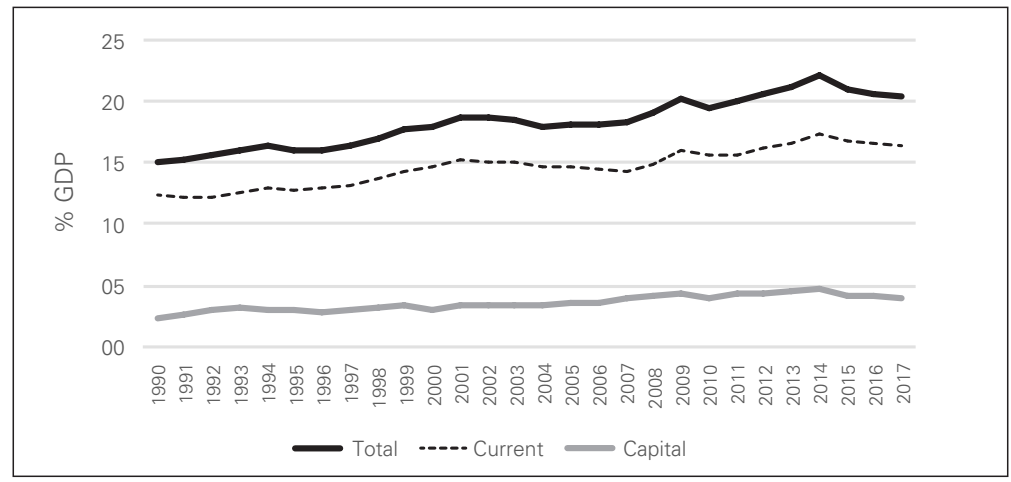

Source: ECLAC database (http://estadisticas.cepal.org/cepalstat/).

Figure 2: Public consumption in Latin America (\%GDP)

(Selected economies)

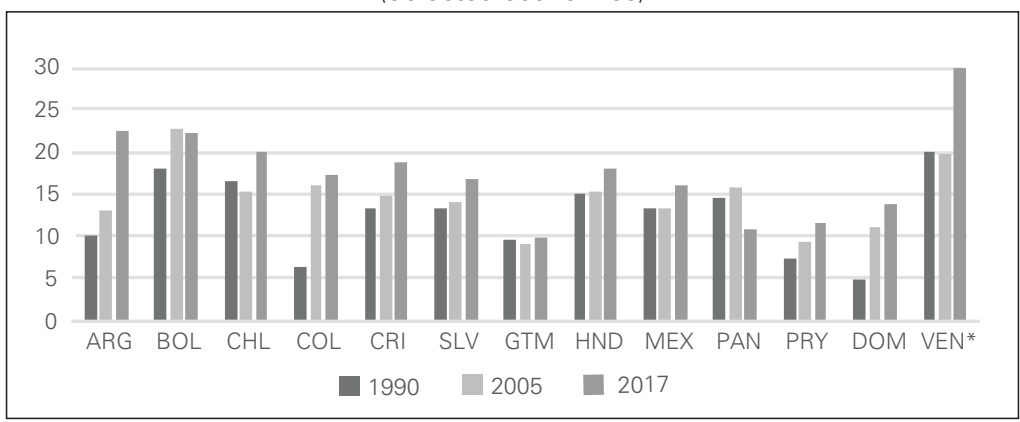

Note: ${ }^{*}$ the final year is 2014.

Source: ECLAC database (http://estadisticas.cepal.org/cepalstat/).

On the other hand, although much more modest, investment spending also exhibits an increasing trend for most of the economies of the sample. It grew on average 2.4 percentage points of GDP between 1990 and 2014, its highest point (see Figure 1). It is important to notice that some countries, like Bolivia and Panama registered substantial increments on government investment. The growth of government investment in Panama is outstanding, going from a tiny $0.4 \%$ in 1990 to a significant $6 \%$ of GDP in 2015 . The other economy where government investment grew substantially is Bolivia. Here government investment quadrupled, going from $4.4 \%$ in 1990 to $16 \%$ in 2014 , though it declined to $12 \%$ of GDP in 2017 (see Figure 3). 
(Selected economies)

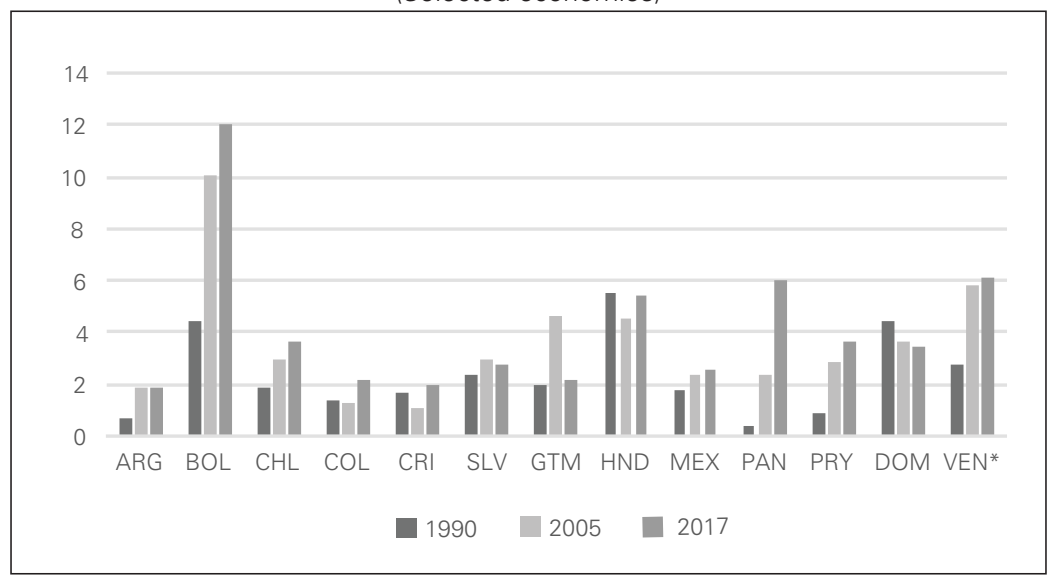

Note: * the final year is 2014.

Source: ECLAC database (http://estadisticas.cepal.org/cepalstat/).

We have, in sum, a period of study where public expenditure has been steadily expanding moderately. In fact, according to Garry and Rivas (2017), during the period 2000 to 2014, economies in Latin American and the Caribbean reported sustained and relatively large fiscal deficits, being the short period after the Great Recession, in 2008, the only one where fiscal consolidation was observed. In any case, it is interesting to have a period of increasing government spending because allow us to hypothesize that our empirical results are reflecting a context of expansionary fiscal policy, similar to the one that prevails in the theoretical analysis of the previous section.

Now, at the same time that public spending has been moderately increasing, the real exchange rate, which is gauged as the ratio of nominal exchange rate to PPP, so increments mean depreciation and decrements appreciation, exhibits large periods of appreciation and depreciation for each individual economy of the sample. The real exchange rate of Bolivia, for example, appreciated during the whole decade of the 1990s, then depreciated until the mid-2000s to then continuously appreciate during the rest of the period of study. A similar pattern is kept for most of the economies in terms of alternative large periods of appreciation/depreciation. The only exceptions in this regard are Guatemala, El Salvador and Venezuela, where the exchange rate has been steadily appreciating (see Figure A1, in the Appendix).

Given this brief background about how our main variables of interest had behaved during the period of interest, the question that arise is how they are related. To answer, we decide to procced by estimating the following equation using panel data techniques:

$$
e_{i t}=\beta_{1}+\beta_{2} X_{i t}^{\prime}+u_{i t}
$$

where $\mathrm{e}_{\mathrm{it}}$ is the real exchange rate for country $i$ during the period $t$ and $X_{i t}^{\prime}$ is the 
vector of regressors, which besides government consumption and government investment, includes a number of variables that have traditionally been identified in the literature to influence the exchange rate (see, for example, Cottani et al., 1990; Cruz, 2015; Seixas et al., 2018). These variables include income per capita (as a proxy of productivity growth), the terms of trade, the current account, the interest rate differential (gauged as the domestic rate of interest minus the United States' interest rate), public debt, international reserves and primary exports.

The reasons to include these variables as well as their expected sign are as follows. In the case of productivity, as we mentioned earlier, it can be the case that higher productivity that the tradable sector experiences will lead to increased wages in this sector. This fact in turn could exert upward pressure on the non-tradable sector's wages. As wages grow, overall prices may follow suit, thereby appreciating the real exchange rate. This is captured by the HBS effect. On the other hand, if idle productive capacity exists or if (wages and) prices do not grow proportionally, increased productivity will not necessarily affect prices in the same direction. Overall, relatively lower prices could decline, depreciating as a result the exchange rate. At the same time, higher productivity means higher income and demand, affecting thus prices, all depending on the size of the income-elasticities of demand. In sum, therefore, productivity could affect either positively or negatively the exchange rate.

The terms of trade are another variable that has been pointed out to affect the exchange rate. In this case, in general terms, it is expected that increases in the terms of trade will lead to higher national income, raising domestic demand and causing the real exchange rate to appreciate. This is, in other words, the pure income effect of an improvement of the terms of trade on the real exchange rate. However, an improvement in the terms of trade can also depreciate the real exchange rate if the substitution effect, as well as the intertemporal ramifications, are taken into account (see Nassif et al., 2011). The idea is that sometime after the initial increase in income, there could be a replacement of tradable goods with non-tradable ones. If the substitution effect prevails over the income effect in the long term, then the real exchange rate will depreciate. The final effect, then, of the terms of trade on the real exchange rate is also unclear (see Edwards, 1988).

We also noted in the previous section, that the current account is a force that also influences the exchange rate. Recall that the basic idea is that as the current account deficit grows (gauged as share of GDP), there will be an increasing expectation that, in order to correct the external imbalance, a depreciation of the exchange rate will be needed. This expectation of currency depreciation could in fact be self-fulfilling as the means to finance the current account deficit start to erode. In sum, an unsustainable current account deficit undoubtedly influences the real exchange rate towards depreciation.

On the other hand, the real interest rate affects the real exchange rate through the financial assets market. Following the Mundell-Fleming model for open economies, the main logic is that real interest rate differentials between domestic and international rates will make investors adjust their portfolios in order to profit from these differentials. In the case that the domestic rate of interest is set above the 
international one, capital inflows are to be expected, appreciating the exchange rate. The opposite will occur in the case the domestic rate of interest being below the international one. In this case, the exchange rate will depreciate as capital flows out. In sum, the real interest differential can either depreciate or appreciate the real exchange rate.

Country risk can also affect the exchange rate through flows of capital. As the country risk increases, investors could decide to leave the country, causing an outflow of capital. At the same time, the government could find harder to sell its bonds abroad, meaning a potential stop of foreign capital. These two events can cause a depreciation of the exchange rate. On the other hand, when the country risk improves, inflows of capital could occur, generating an appreciation. To capture country risk, we decide to include in our estimation the size of public debt.

To capture the "Dutch disease", which, as is well-known, appreciates the exchange rate, we include primary exports. The inclusion of this variable is particularly relevant as all of the countries of our sample (except for Mexico) export chiefly primary commodities. The prices of these goods are quite volatile and in this sense are subject to major booms or slumps on other economies or regions. During the first decade of this century, Latin America witnessed an episode, known as the "super-cycle", where the rapid economic growth of other regions (like Asia and Europe, important trade patterns of Latin American economies of the sample are located) pushed the demand for primary commodities in the region, increasing their prices. So, it is likely that the exchange rate would have been affected this via.

Finally, since the mid-1990s, the accumulation of international reserves has been increasing around the world, and Latin America has not been the exception (see Cruz, 2015). According to recent literature, this variable might have influenced the exchange rate either towards appreciation or depreciation. The reason for this is that due to precautionary (namely liquidity) reasons, centrals banks could prefer the exchange rate to move in either direction, so that they do not to decrease their reserves. However, under a mercantilist approach, monetary authorities could prefer to intervene in the foreign exchange market to stabilize an already undervalued currency. On the other hand, it is also possible that in order to avoid any disturbing effect on its own economy, the existence of large hoardings of international reserves might postpone the necessary adjustments of the exchange rate to correct an external balance - namely devaluing it as necessary. Under this logic, but having in mind an inflation targeting framework, the vast resources that the central bank accumulates allow it to intervene in the foreign exchange market in order not only to avoid abrupt exchange rate volatility but also to maintain its overvaluation, so inflation is kept withing its target. In sum, the existence of large official reserves puts either upward or downward pressure on the exchange rate (see Cruz, 2015, p. 491).

So, we include as regressors in our real exchange rate equation the following variables: government consumption $(g c)$ and government investment $(g k)$, both gauged as a share of GDP; the real income per capita in US dollars $(y p c)$ as a proxy of the evolution of productivity; the terms of trade $(t t)$; the current account as a share of GDP $(c c)$; the interest rate differential $\left(r-r^{*}\right)$ (gauged as the difference of 
the domestic real rate interest minus the US real rate of interest); we also include as a share of GDP the following variables: exports of primary goods $(x p)$; public debt $(p d)$ and international reserves $(i r)$. It is important to notice that we assume that there is not a single, particular value to which the real exchange rate converges, and thus deviates. It is instead a variable that it is meant to vary towards different equilibria in order keep internal and external equilibrium.

The data come from the World Development Indicators of the World Bank (http:// databank.worldbank.org/), the ECLAC statistics (http://estadisticas.cepal.org/) and the Penn World Table (http://www.rug.nl/research/ggdc/data/pwt/), and all the variables, except the current account, were transformed into logs. It is important to point out that we took as given the variables from these databases and that we only construct the real exchange rate as the ratio of nominal exchange rate to PPP $(e)$. For the sake of robustness on the estimated results and thus on the inference that is made from them, we estimate the equation using four different estimators: random and fixed effects, panel-corrected standard error and instrumental variables, (RE), (FE), (PCSE) and (IV), respectively. This last technique allows us to correct for potential endogeneity among the regressors and the error term. Following Arellano and Bond (1991), we used the dependant and independent variables lagged one or two terms as instrumental variables.

Table 1 shows the results of the estimated equation. Each column ( 1 to 4 ) corresponds to each estimator. The idea is to assess if the estimated parameters associated to public investment and consumption change dramatically in size and sign when estimated with different estimators. As can be seen, their size is similar under FE and RE, but change, though not substantially, when estimated with PCSE and IV. At the same time, they maintain the same sign, but they do not keep their statistical significance along the four estimations. On the other hand, along the four estimators, there is no evidence of omitted variables as the F or Wald test, suggests. The Hausman test, indicates that the FE estimator should be chosen over the RE estimator, at the $1 \%$ of significance level. To correct over potential heteroskedasticity problems that might be present in this estimation, however, we shall prefer the results obtained through the PCSE estimator (column 3). Finally, a potential source of endogeneity comes from simultaneity (see Barros et al., 2020). To correct for this (or other potential sources such as measurement errors), we decided to estimate the equation using IV. The Sargan test for orthogonality of the instruments and the error term, suggests that the model is adequate. In sum, thus, the best estimated parameters come from either the PCSE or the IV estimators (columns 3 and 4, respectively). The former, in fact, can be seen from a static point of view, whereas the latter from a dynamic one.

Following the IV estimated parameters, the key findings to note are as follows. In the first place, government consumption has a negative sign and is statistically significant at the $1 \%$ confidence level. The result indicates that public consumption appreciates the real exchange rate, a result in line with the existing literature. In other words, for our sample of economies, there is statistical evidence to argue that government consumption does affect the exchange rate. The size of the impact is, 
nevertheless, small. It will take 10 percentage points increase of government consumption to appreciate the exchange rate 2.02 percentage points. The effect of government consumption on the exchange rate is, as can be seen, quite small.

Table 1: Latin America. Determinants of the real exchange rate, 1990-2017

(Dependent variable: real exchange rate, e)

\begin{tabular}{|c|c|c|c|c|}
\hline Variable & $\begin{array}{l}\mathrm{FE} \\
\text { (1) }\end{array}$ & $\begin{array}{l}\text { RE } \\
(2)\end{array}$ & $\begin{array}{c}\text { PCSE } \\
(3)\end{array}$ & $\begin{array}{l}A B \\
(4)\end{array}$ \\
\hline \multirow[t]{2}{*}{ gc } & -0.083 & -0.108 & $-0.234^{* * *}$ & $-0.202 * * *$ \\
\hline & (0.145) & $(0.131)$ & (0.059) & (0.055) \\
\hline \multirow[t]{2}{*}{ gk } & 0.119 & $0.111^{*}$ & $0.029 *$ & $0.039 *$ \\
\hline & (0.073) & $(0.067)$ & $(0.017)$ & $(0.022)$ \\
\hline \multirow[t]{2}{*}{ урс } & -0.178 & $-0.228 * * *$ & $-0.246 * * *$ & $-0.235 * * *$ \\
\hline & $(0.170)$ & $(0.066)$ & $(0.052)$ & (0.065) \\
\hline \multirow[t]{2}{*}{ cc } & $0.012^{*}$ & $0.011^{* *}$ & $0.006^{* * *}$ & $0.006^{* * *}$ \\
\hline & $(0.006)$ & $(0.005)$ & $(0.002)$ & $(0.002)$ \\
\hline \multirow[t]{2}{*}{$r-r^{*}$} & $-0.004 *$ & $-0.004^{*}$ & -0.001 & $-0.001^{*}$ \\
\hline & $(0.002)$ & $(0.002)$ & $(0.001)$ & $(0.001)$ \\
\hline \multirow[t]{2}{*}{ tt } & -0.136 & $-0.117^{* *}$ & -0.044 & $-0.056^{*}$ \\
\hline & $(0.080)$ & $(0.056)$ & $(0.046)$ & (0.033) \\
\hline \multirow[t]{2}{*}{ ir } & -0.059 & -0.047 & $0.028^{*}$ & 0.000 \\
\hline & $(0.040)$ & $(0.037)$ & $(0.017)$ & $(0.015)$ \\
\hline \multirow[t]{2}{*}{$\mathrm{px}$} & -0.001 & -0.003 & $0.069 * * *$ & $0.066 * * *$ \\
\hline & $(0.045)$ & (0.045) & (0.018) & (0.016) \\
\hline \multirow[t]{2}{*}{$\mathrm{pd}$} & $0.185^{* *}$ & $0.171 * *$ & $0.219 * * *$ & $0.255^{* *}$ \\
\hline & $(0.077)$ & (0.075) & (0.034) & $(0.021)$ \\
\hline \multirow[t]{2}{*}{ constant } & $2.433^{*}$ & $2.864 * * *$ & $2.567 * * *$ & $2.188^{* * *}$ \\
\hline & $(1.208)$ & $(0.780)$ & $(0.544)$ & $(0.489)$ \\
\hline \multirow[t]{2}{*}{ e_1 } & & & & $0.311 * * *$ \\
\hline & & & & $(0.048)$ \\
\hline Grups & 322 & 322 & 322 & 288 \\
\hline Obs & 13 & 13 & 13 & 13 \\
\hline$R^{\wedge} 2$ & 0.4346 & 0.4907 & 0.5657 & \\
\hline \multirow{2}{*}{ F or Wald test } & $8.15^{* * *}$ & $99.90 * * *$ & $132.68^{* * *}$ & $835.02 * * *$ \\
\hline & $F(9,12)$ & $\chi 2(9)$ & $\chi 2(9)$ & $\chi 2(10)$ \\
\hline \multirow{2}{*}{ Sargan test } & & & & 85.227 \\
\hline & & & & $\chi 2(74)$ \\
\hline Instruments & & & & 85 \\
\hline Hausman test & \multicolumn{2}{|c|}{$20.59 * * *$} & & \\
\hline
\end{tabular}

Notes: ${ }^{* *} p<0.001,{ }^{*} p<0.05,{ }^{*} p<0.01$. Robust standard errors are in parenthesis. 
There might be various reasons that explain this result. It could be the case that firms are far from full employment. Data from the OECD database indicates, for example, that Mexico, had on average a level of capacity utilisation in the manufacturing sector of $80 \%$ during $1995-2016$. Argentina, used on average $71 \%$ of the installed productive capacity in the manufacturing sector during 2009-2016. In other words, even the most dynamic, highly supply elastic sector in these economies has been far from full capacity utilisation. So, if demand increases, it is hardly difficult to expect a major increase in prices and thus a real appreciation.

It could also be the case that the multiplier is low, having small effects on effective demand. In this respect, we must recall that the trade liberalization strategy in which the region has engaged since the decade of 1990, has led to an important increase of imports, impacting negatively on the size of the multiplier. In the case of Mexico, for example, one of the economies that has embraced trade openness more radically, the multiplier has decline about two points, going from 3.9 in 1986 to 1.8 in 2016. Finally, it is expected that the income elasticity of demand for services in these economies is below unity, which could be another explanation of the low effect of government consumption on the exchange rate.

Government consumption is not, however, the only force that push the exchange rate towards appreciation. Our results indicate that the interest rate differential., the terms of trade and productivity also contribute to appreciate the exchange rate. We have, in sum, at least three additional variables that are affecting the exchange rate towards appreciation.

Second, in the case of government investment, it affects the exchange rate towards depreciation. The estimated parameter is statistically significant and, in a similar vein to public consumption, the effect is rather small. Overall, this result confirms what we discussed at the theoretical level: that government investment has the potential for influencing positively the exchange rate. In this sense, it is worth noting that the amounts of government investment spent in Latin America (sometimes quite large like in Bolivia and Panama) had had a positive impact on the exchange rate, and thus on the traded sector.

Notwithstanding the relevance of this finding, a caveat remains is the sense of through which channel exactly government investment is affecting the exchange rate. One via is the demand channel, which under conditions of idle productive capacity, leads firms to keep prices stable. Another is the positive effect that government investment has on productivity and this in turn on prices and on real the exchange rate. In fact, the increased income and demand coupled with the prevalence of a high (above unity) income elasticity of demand for manufactures and a low (below unity) income elasticity of demand for services may also explain why the real exchange rate depreciates.

Finally, the current account deficit is statistically significant and has a positive sign, suggesting that it has influenced the exchange rate to devaluing. The effect of the current account deficit on the exchange rate is, according to the estimated pa- 
rameter, nevertheless negligible. In addition, primary exports and the country risk are forces that also depreciate the exchange rate. Interestingly, international reserves seem to have no influence at all on this variable.

What is the relevance of our main findings? Well, the fact that, on the one hand, public consumption appreciates the real exchange rate and, on the other, that public investment depreciates it, but that these affects are rather small, allows us to suggest that the Latin American economies of our sample could (must) implement expansionary fiscal policies to stimulate and promote growth, based mainly on an aggressive government investment strategy.

Due to the abandonment of expansionary public investment strategies (and to other policies, like a competitive exchange rate strategy, an accommodative monetary policy, etc.), the transition towards the production and export of complex goods, something that marks advanced stages of economic development), has not happened yet in Latin America. Currently, as we mentioned, most of the Latin American economies still remain mainly producers and exporters of primary commodities. The share of commodity exports on total exports is around $50 \%$ in most of the economies of Latin America. The exception is the Mexican economy, whose exports are mostly manufactured. They represent more than $85 \%$ of total exports since the late 1990s, yet these exports are maquila-type, implying that they are just ensemble in Mexico, with very low domestic value added. In this sense, it can be argued that Mexico's export-led growth model has not been successful so far.

Public investment, as has been shown (see Amsden, 1989; UNCTAD, 2003), has been a key ingredient to explain why economies, particularly China and the first and second tier of East Asian tigers, developed successfully. Interestingly, in these East Asian economies, government investment alone attained around $15 \%$ of GDP during the early 1980s (see Page, 1994). In these economies, public investment was used to create the structures to build up or upgrade the technological capabilities for high value-added export growth. This generally mean the ability to compete in high technology sectors, which implies the need for the development of new products and processes that require not only investment in R\&D but also the formation of linkages between domestic firms to develop the whole production system. The essence of a public investment strategy is a commitment by the government to the support of industrial development (Arestis and Sawyer, 1998, p. 190-191). This implies that roads, power plants, schools, hospitals, dams, R\&D centres and so on are to be built to this end, and this infrastructure has to be developed mainly, and sometimes exclusively, via government spending (see Fraga, et al., 2016). In fact, many of the advances that the capitalism has witnessed could not been understood without a large share of government investment (see Mazzucato, 2013).

In addition, the maintenance of a stable and undervalued exchange rate has been a crucial ingredient in the performance of these economies (see Amsden, 2001; Rodrik, 2003 and 2008; Gala, 2008 Steinberg, 2015; Habib et al., 2016; see also Bresser-Pereira, 2012). A competitive exchange rate strategy promotes exports via 
prices and at the same time discourages imports. This in turns results in equilibrium or even surplus of the trade balance, a necessary condition to grow uninterruptedly. So, this strategy also aided these economies to transform their productive capabilities to produce and export sophisticated goods.

Summarising, a great deal of the success in climbing up the ladder of development has been the result of an adequate short term competitiveness strategy, based on the maintenance of a competitive exchange rate, coupled with a long term industrial strategy, underpinned by government expenditure, particularly of the investment kind. The empirical evidence of these successful economies points out, thus, that an expansionary fiscal stance and a competitive exchange rate strategy are not only necessary but also compatible.

So, by implementing an integrated strategy, the economies of our sample could indeed set the basis for a positive productive transformation. In addition, according to our results, government invest has the potential to offset the forces that could appreciate the exchange rate. Government investment in this sense may counterbalance the forces that tend to appreciate the exchange rate, particularly when these economies, as we stressed, have found very difficult to adopt a purposely competitive exchange rate strategy.

In sum, the economic policy that our results support is to aid the tradable sector via two channels: on the one the hand, via the quality of the goods produced, a characteristic that can be achieved only via public investment. On the other, which is consequence of government investment, through prices, keeping a competitive (devalue) exchange rate. This is, after all, a proved route of economic development and we have shown here that there are not theoretical neither empirical arguments against this strategy.

\section{CONCLUSIONS}

In this paper, we attempted to show at the empirical level that the final effect of government spending on the exchange rate is not as straightforward as is suggested generally in the literature. We used data of thirteen selected Latin America economies to explore that relationship. We estimated an exchange rate equation for the period 1990-2017. We included in the equation, besides government investment and government consumption, other variables that, according to the literature, affect the exchange rate. Our estimated results indicated that government investment depreciates it, whereas government consumption appreciates it. In both cases, it is worthy to mention, the effect is rather small. This finding is relevant because allows to suggest that not much concern needs to be put on the exchange rate when deciding to set an expansionary fiscal policy. In this sense, there is room for economies in the region to attempt to promote growth and development based mainly on 
government investment, without fearing of harming the exchange rate. Public investment, as the recent experiences in Asia have shown, has been key to climb up the ladder of economic development.

\section{REFERENCES}

Amsden, A. (1989). Asia's next giant: South Korea and late industrialization, Oxford: Oxford University Press.

Arellano, M. and Bond, S. (1991). "Some test of specification for panel data: Monte Carlo evidence and an application to employment equations". Review of Economic Studies, 58: 277-297.

Arestis, P. and Sawyer, M. (1998). "Keynesian economic policies for the new millennium”. Economic Journal, 108: 181-195.

Aschauer, D. (1989). "Is public expenditure productive?". Journal of Monetary Economics, 23: 177200.

Barros, L., Castro, F.H., Da Silveira, A., Bergmann, D., (2020). "Endogeneity in panel data regressions: methodological guidance for corporate finance researchers". Review of Business Management, 22: 437-461. doi:10.7819/rbgn.v22i0.4059

Bénetrix, A. and Lane, P. (2013). "Fiscal shocks and the real exchange rate". International Journal of Central Banking, 9(3): 1-32.

Bhaduri, A. and Matzner, E. (1990). "Relaxing the international constraints on full employment". Banco Nazionale del Lavoro Quarterly Review, 172: 49-62.

Bergstrand, J. (1981). "Structural determinants of real exchange rates and national price levels: some empirical evidence”. American Economic Review, 81(1): 325-334.

Bresser-Pereira, L. C. (2012). "Structuralist macroeconomics and the new developmentalism”, Brazilian Journal of Political Economy, 32(3): 347-366.

Caputo, R. and Fuentes, M. (2012). "Government spending and the real exchange rate: a cross-country perspective”. Documento de Trabajo no. 655, Banco Central de Chile, 1-20.

Cakrani, E., Pranvera, P. and Koprencka, L. (2013). “Government spending and real exchange rate case of Albania”. European Journal of Sustainable Development, 2(4): 303-310.

Cottani, J., Cavallo, D. and Shahbaz, K. (1990). "Real exchange rate behavior and economic performance in LDCs", Economic Development and Cultural Change, 39(1): 61-76.

Cruz, M. (2015). "International reserves and growth: assessing the mercantilist motive in Latin America". Journal of Post Keynesian Economics, 37(3): 481-502

Chinn, M. (1999). "Productivity, government spending and the real exchange rate: evidence for OECD countries", in Equilibrium exchange rates, Edited by R. MacDonald and J. Stein, Boston: Kluwer Academic Publishers, 163-190.

Davidson, P. (2007). John Maynard Keynes, United Kingdom: Palgrave.

De Gregorio, J., Giovannini, A. and Wolf, H. (1994". "International evidence on tradable and nontradables inflation”. European Economic Review, 38: 1225-1244.

Edwards, S. (1988). "Real and monetary determinants of real exchange rate behavior: theory and evidence from developing countries". NBER Working Paper Series, no. 2721, 1-51

Fraga, C., Briseño, I. and Heras, M. (2016). "Multiplicadores y coordinación fiscal y monetaria en Argentina, Brasil, Chile y México para el desarrollo", Problemas del Desarrollo, 47(185): 11-34.

Froot, K. and Rogoff, K. (1991). "The EMS, the EMU and the transition to a common currency". NBER Working Papers Series, 1-58.

Gala, P. (2008). "Real exchange rate levels and economic development: theoretical analysis and econometric evidence". Cambridge Journal of Economics, 32(2): 273-288. 
Galstyan, V. and Lane, P. (2009a). "The composition of government spending and the real exchange rate". Journal of Money, Credit and Banking, 41(6): 1233-1249.

Galstyan, V. and Lane, P. (2009b). "Fiscal policy and international competitiveness: evidence from Ireland". The Economic and Social Review, 40(3): 299-315.

Ganelli, G. and Tervala, J. (2015). "The welfare multiplier of public infrastructure investment”. IMF Working Paper No. 40, 1-28

Garry, S. and Rivas, J. (2017). "An analysis of the contribution of public expenditure to economic growth and fiscal multipliers in Mexico, Central America and the Dominican Republic, 19902015", Studies and Perspectives Series no. 173, ECLAC-UN, 1-57.

Habib, M., Mileva, E. and Stracca, L. (2016). "The real exchange rate and economic growth: revisiting the case using external instruments”. European Central Bank Working Paper Series No. 1921/ June, 1-33.

Hebous, S. and Zimmerman, T. (2016). "Can government demand stimulate private investment?: Evidence from U.S. Federal procurement”. IMF Working Paper Series No. 60, 1-34.

IMF, (2014). World Economic Outlook: Legacies, clouds, uncertainties, Washington DC: IMF.

Kaldor, N. (1966). Strategic factors in economic development, Ithaca: Cornell University Press.

Kollmann, R. (2010). "Government purchases and the real exchange rate". Open Economies Review, 21(1): 49-64.

Mazzucato, M. (2013). The entrepreneurial state: debunking public vs private sector myths, New York: Anthem Press.

Moreno, M. and Segura-Ubiergo, A. (2014). "Real exchange rate appreciation in emerging markets: Can fiscal policy help?". IMF Working Paper No. 14/1, 1-24.

Nassif, A., Feijó, C. and Araújo, E. (2011). “The long-term 'optimal' real exchange rate and the currency overvaluation trend in open emerging economies: the case of Brazil" UNCTAD Discussion Papers no. 211, 1-26.

Obstfeld, M. and Rogoff, K. (1996). Foundation of international macroeconomics, USA: MIT Press.

OECD. (2016). OECD Economic Outlook, Volume 2016, Issue 1: Preliminary Version, Paris: OECD Publishing

Page, J. (1994). "The East Asian miracle: four lessons for development policy”, in NBER Macroeconomics Annual 1994, Edited by S. Fisher and J. Rotemberg, USA: MIT Press, 219-282.

Pressman, S. (1994). “The composition of government spending: does it make any difference?”, Review of Political Economy, 6(2): 221-239.

Ravn, M., Schmitt-Grohe, S. and Uribe, M. (2012). "Consumption, government spending, and the real exchange rate". Journal of Monetary Economics, 59(3): 215-234.

Ricci, L., Milesi-Ferretti, G. and Lee, J. (2008). "Real exchange rates and fundamentals: a cross-country perspective”. IMF Working Papers No. 08/13, 1-27.

Rodrik, D. (2008). "The real exchange rate and economic growth". Brookings Papers on Economic Activity, 2: 365-412.

Rodrik, D. (2003). “Growth strategies”. NBER Working Paper Series, no. 10050, 1-60

Rowthorn, R. and Ramaswamy, R. (1999). “Growth, trade and deindustrialisation”. IMF Staff Papers, 46(1): 18-41.

Sachs, J., and C. Wyplosz. (1984). "Real exchange rate effects of fiscal policy". NBER Working Paper No. $1255,1-47$

Seixas, L., Jaime Jr., F. and Missio, F. (2018). "Determinants of the real exchange rate in the long-run for developing and emerging countries: a theoretical and empirical approach", International Review of Applied Economics, 32(1): 62-83.

Smithin, J. (1989). "The composition of government expenditures and the effectiveness of fiscal policy, in New directions in Post-Keyensian economics, Edited by J. Pheby, England: Edward Elgar, 209-227

Steinberg, D. (2015). Demanding devaluation. Exchange rate politics in the developing world, New York: Cornell University Press 
Thirlwall, A. (2003). Trade, the balance of payments and exchange rate policy in developing countries, UK: Edward Elgar.

UNCTAD (2003). Trade Development Report. Capital accumulation, growth and structural change, New York and Geneva: United Nations.

\section{APPENDIX}

Figure A1: Effective real exchange rate in Latin America (logs), 1990-2016 (Selected economies)

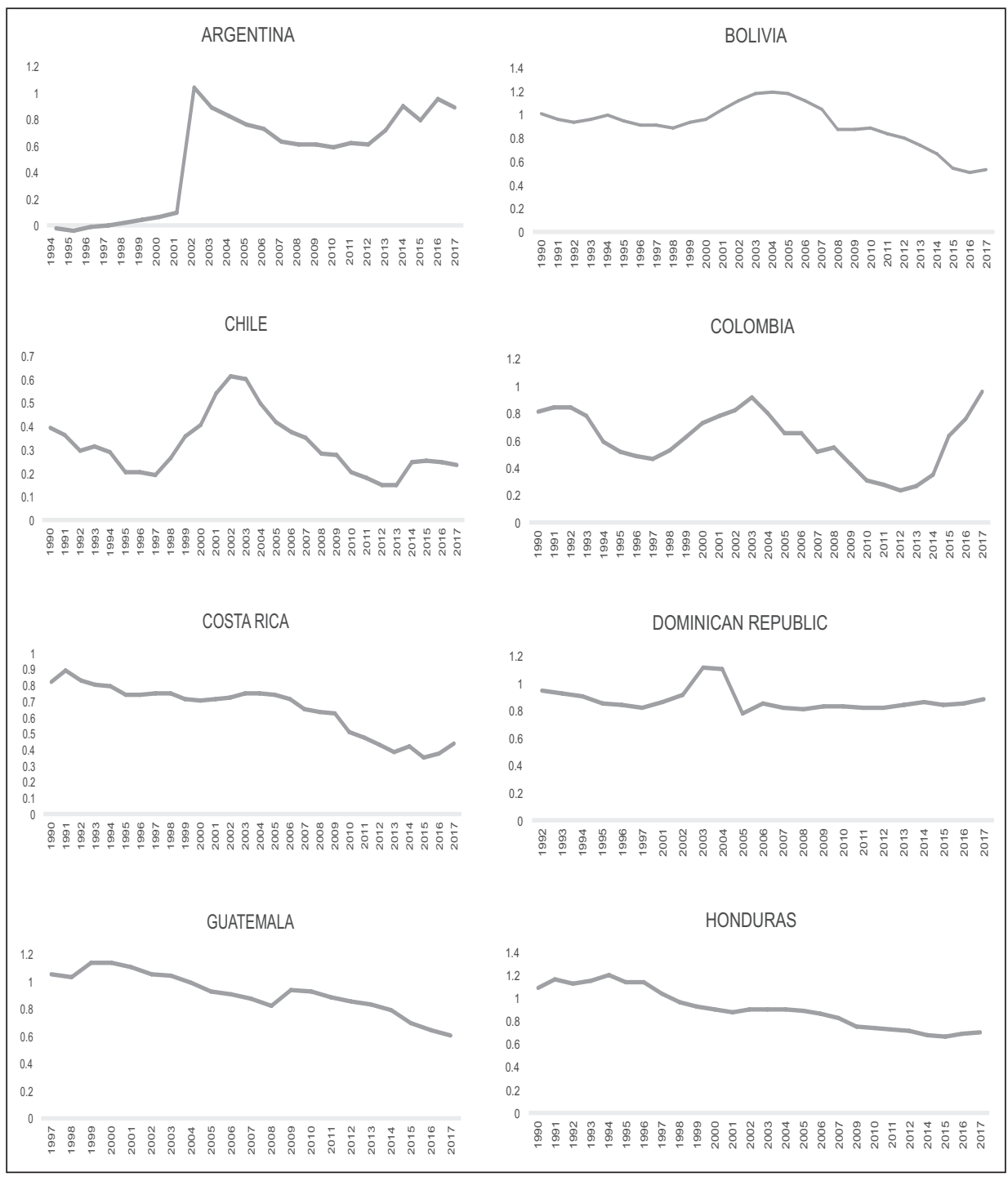




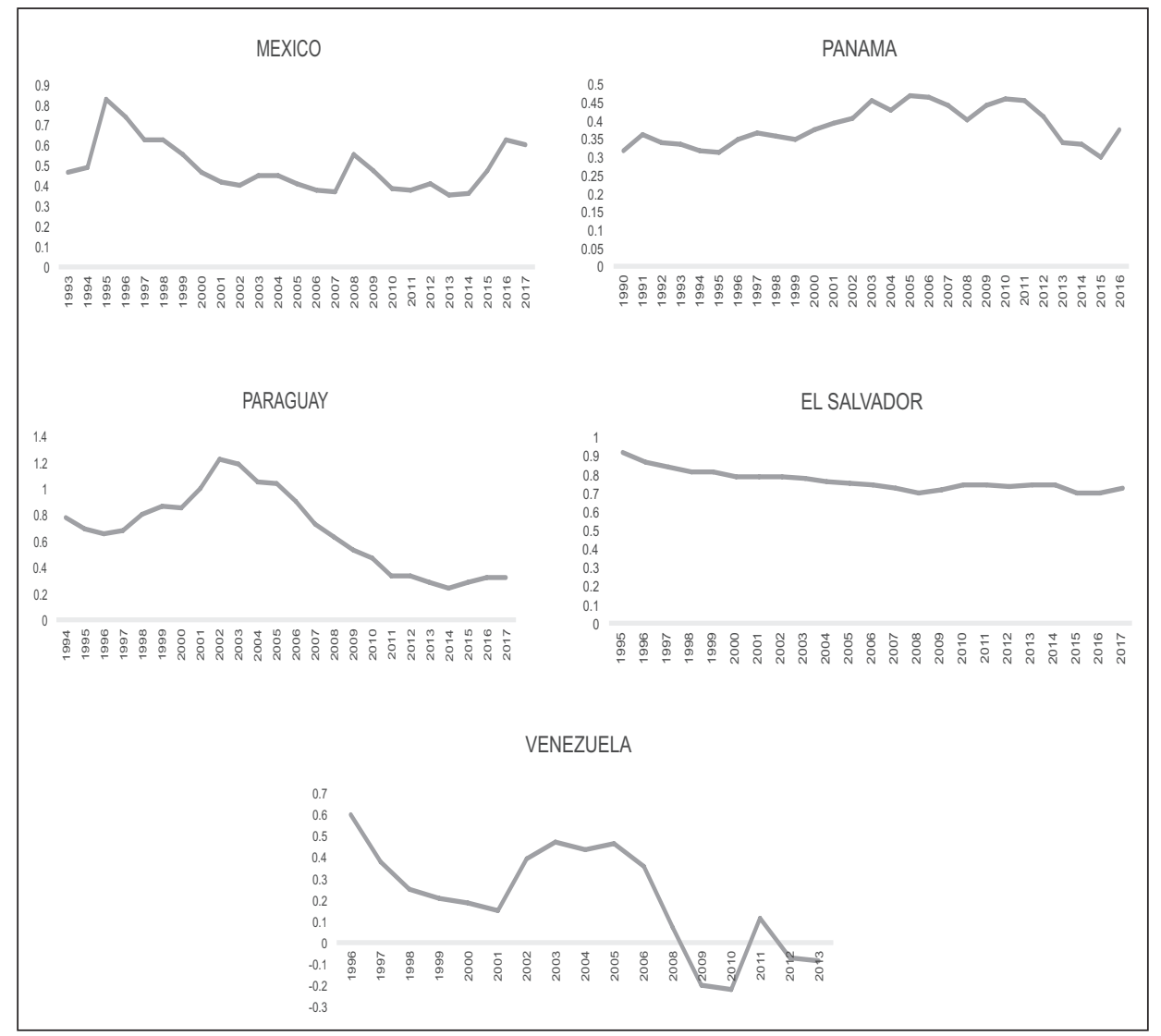

Source: Own elaboration with data of the Penn World Tables (http://www.rug.nl/research/ggdc/data/pwt/) and the ECLAC (http://estadisticas.cepal.org/). 